Discussion papers of the

Max Planck Institute for

Research on Collective Goods

Bonn 2016/17

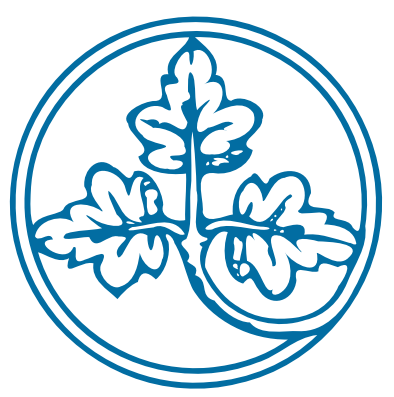

Diffusion of Legal Innovations:

The Case of Israeli Class Actions

Christoph Engel

Alon Klement

Keren Weinshall

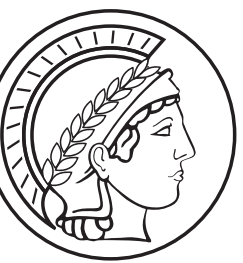




\section{Diffusion of Legal Innovations: The Case of Israeli Class Actions}

Christoph Engel / Alon Klement / Keren Weinshall

June 2017

This version January 2018 


\title{
Diffusion of Legal Innovations: The Case of Israeli Class Actions ${ }^{*}$
}

\section{Christoph Engel / Alon Klement / Keren Weinshall}

\begin{abstract}
In law and economics, it is standard to model legal rules as an opportunity structure. The law's subjects maximize expected profit, given these constraints. In such a model, the reaction to legal innovation is immediate. This is not what we observe after class actions have been introduced into Israeli law. For a long time, the new remedy is almost unused. Then the adoption process gains momentum. We discuss alternative options for theorizing the effect. We find that market entry is not only explained by the available information about profitability, but also by the adoption pattern of others. When deciding whether to bring further claims, law firms also react to the experiences they have made themselves. We thus explain the pattern by individual and social learning, and cannot exclude mere social imitation.
\end{abstract}

JEL: D02, D21, D22, D83, K10, K41

\footnotetext{
* In law and economics, it is standard to model legal rules as an opportunity structure. The law’s subjects maximize expected profit, given these constraints. In such a model, the reaction to legal innovation is immediate. This is not what we observe after class actions have been introduced into Israeli law. For a long time, the new remedy is almost unused. Then the adoption process gains momentum. We discuss alternative options for theorizing the effect. We find that market entry is not only explained by the available information about profitability, but also by the adoption pattern of others. When deciding whether to bring further claims, law firms also react to the experiences they have made themselves. We thus explain the pattern by individual and social learning, and cannot exclude mere social imitation.
} 


\section{Introduction}

The legislator speaks and nobody listens. In the world of standard economic models, this cannot happen. These models view legal entitlements as part of agents' opportunity sets. Agents utilize a new legal entitlement if this increases their expected profit. They assess the costs and benefits of the available alternatives, assign (possibly subjective) probabilities to uncertain events, calculate the expected value of each alternative, and go for their best choice. Reality is different. It sometimes takes years before a new legal remedy is widely used. Legal reform does not stop with the adoption of the rule in Parliament or court. It requires implementation by individual agents who learn about their new entitlement (Engel 2008), and trust it.

In this paper, we argue that the implementation of legal innovations should be modeled as a dynamic process that requires individual and social learning, akin to the diffusion of product innovations. The innovation literature is interested in a product, trend, technology or ideology that is newly introduced into a system (Rogers 2003: 12f.). Successful spread of an innovation depends not only on its intrinsic quality and its suitability for potential adopters, but also on the particular structure of the social system into which the innovation is released, and on influence patterns among the members of that system. The diffusion of innovation is "the process by which the prior adoption of a trait or practice in a population alters the probability of adoption for the remaining non-adopters" (Strang 1991: 325). The feedback effects from prior adoption decisions by others to one's future decisions are explained by alternative mechanisms, from naïve imitation or "social influence" through conformity-seeking over mechanisms that at least locally react to information about others' success, to "social learning" (Chamley 2003). The latter assert that adoption is based on Bayesian updating in the light of accumulating evidence about the profitability of the innovation (Bikhchandani, Hirshleifer et al. 1998).

Recent legal scholarship has studied the diffusion of legal rules from one legal system to another - for example, transplants of institutions between countries, states and courts (Twining 2004, Twining 2005, Romano 2006, Twining 2006, Westbrook 2006, Goderis and Versteeg 2014, Graham 2015). In this paper, we use diffusion models to predict how private attorneys, i.e. legal professionals, utilize a new remedy.

The Israeli law of class action is an ideal case for testing our conceptual claim. The remedy has been newly introduced in 2006. Yet for almost a year, the remedy has only rarely been used. Only after a long incubation phase, class actions have been filed more frequently. From then on, their frequency has grown exponentially.

We have collected data on all class actions that have been filed between the law becoming effective in April 2006 and August $2012(\mathrm{~N}=2,056)$. The cases were drawn from computerized court records and were coded by law students who read all relevant case documents, including motions, hearing protocols, settlement agreements and court decisions. We know 
which law firm filed which case, which court and which judge handled the case, its subject matter, and the case outcome.

In many respects, class actions are well suited to study the dynamics that underlie the spread of legal innovations. Class actions are almost exclusively initiated by attorneys, who search for available causes of action and then look for class members who may act as representatives (Fisch 1997, Hensler, Dombey-Moore et al. 2000, Gilles and Friedman 2006). Class attorneys bear most of the costs and risk in class action litigation. Through contingent fees, they are also the primary beneficiaries if they win or settle the case. In addition, Israeli law mandates that all class action filings and outcomes are published in an online open register. ${ }^{1}$ This offers an opportunity to examine the diffusion of a legal innovation among presumably rational and highly informed agents. Finally, it is relatively easy to measure and compare the benefits adopters gain from using the innovation, because the individual lawyer's fee is determined by the court. This renders it possible to disentangle individual from social learning.

We investigate whether class action filing patterns are in line with diffusion paths identified in the literature on product diffusion (Young 2009, Shur-Ofry, Fibich et al. 2016). For each law firm in our dataset, we distinguish between its first class action suit ("market entry") and its subsequent class action filings ("market participation"). While the former can only be a result of social effects, the latter is potentially also influenced by individual learning.

We find that market entry decisions are independently explained by the participation of others in the market, and by their success. Market participation is explained by participation and success of others, and it is additionally explained by a law firm's own success rate in previous class actions it has filed. The effect of individual success shows that firms learn from their own experiences as well.

Since, conditional on the effect of participation by others, there is a significant effect of others' success, the adoption of the new remedy cannot be exclusively driven by imitation, but involves social learning. However, since we find a separate effect of the participation of others on entry, and since this effect is already present when only very few cases are closed, imitation cannot be ruled out. With our data, we cannot, however, discriminate between the two: law firms may simply imitate other law firms, or they may deem the decision of other firms to engage in this market to be informative. While nobody can assess with certainty whether this line of business is profitable as long as only few cases have been closed, arguably each law firm that brings a case has assessed the prospect, and deemed it positive. This allows newly entering law firms to decide on a broader information base. If they reason in a Bayesian manner, the number of cases that have been filed is new information that allows them to update their own (prior) assessment.

1 See section 28 of CAL. The register is intended, among other things, to enable the general public and the represented class to participate in the process (for example, to oppose an agreed compromise) and to prevent parallel claims. 
We are fortunate to have complete data. But it includes only class actions filed in Israel since the introduction of the remedy. We cannot compare Israel with another jurisdiction that does not offer the remedy. Israeli law firms have not been randomly assigned to this treatment. We only observe law firms that, at least once during our period of observation, have filed a class action. In this respect, our sample is selective. For all these reasons we are not in a position to identify the causal effect of the availability of class actions on law firms' choice among alternative remedies or lines of business, or the causal effect of one of our explanatory variables on the decision of a law firm not in our sample to enter the market. This is, however, not our research question. We want to test alternative theories for the diffusion of legal innovation. The critical empirical question we address is: is our data consistent with some and inconsistent with other theoretical claims for the diffusion process? Since we only perform this test for Israeli class action, we flag the exercise out as a quantitative case study.

The paper unfolds as follows: In the next section, we introduce main aspects of the vast diffusion literature and discuss the small, yet growing, discourse on the diffusion of legal innovations. Section 3 presents our case study: we elaborate on the substance and enactment process of the Israeli class action law, describe the generation of the data, and present our hypotheses. Section 4 reports results and puts the findings into perspective. The paper concludes with a discussion of the contribution of our approach to the existing body of socio-legal knowledge, and its limitations.

\section{Literature and Theory}

\section{a. Theories of Innovation Diffusion}

The extensive literature on innovation diffusion spans economics, marketing, sociology and anthropology. ${ }^{2}$ Diffusion studies investigate the feedback effect from prior decisions to adopt an innovation on future decisions made by others. Most feedback effects follow an S-shaped pattern, where the temporal rate of cumulative adoption is derived from a symmetric bellshaped curve that describes the distribution of adopters (see Figure 1). The process starts out slowly with "innovative” adopters who are willing to try out the new product or process independently of others. They often possess more financial resources and information, allowing them to sustain high degrees of uncertainty and a possible loss from an unsuccessful innovation. The diffusion process gains momentum with early adopters, who usually enjoy opinion leadership status. The early adopter is respected by her peers and serves as a role-model for many other members of a social system (Rogers 2003: 282-284). After a while the number of new adopters rises sharply and a successful innovation reaches a "tipping point," from which moment on its further diffusion is almost automatic (Shur-Ofry 2009). In the end, laggards

2 For reviews of this literature, see for example: Rogers (2003), Greenhalgh, Robert et al. (2004), Baptista (1999) and Diebolt, Mishra et al. (2016). 
slowly join in, the diffusion curve flattens and ultimately reaches a saturation point (ShurOfry, Fibich et al. 2016).

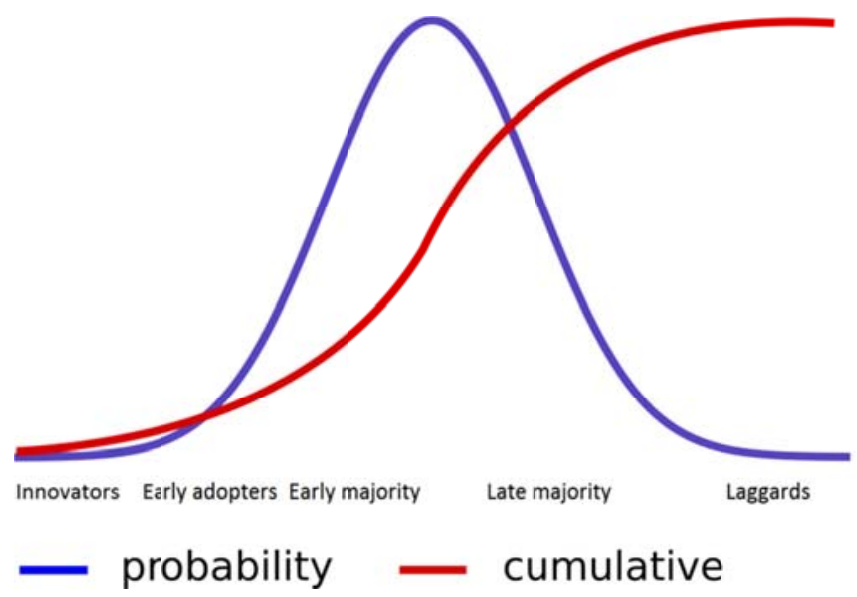

Figure 1

Stylized Diffusion Path of a Product or Process Innovation

Various theoretical models seek to explain the S-shaped diffusion curve (Young 2009). A basic model was introduced in the marketing literature by Bass (1969). According to this model, innovations spread much like a contagious disease. Adoption occurs as potential adopters are exposed to actual adopters and thereby learn about the new technology. Adoption is slow at first, as few individuals know about the innovation. As more people adopt the technology, information about it spreads, leading to a period of rapid adoption.

The sociological literature focuses on the importance of social pressure for individual adoption decisions. According to this model, the spread of innovation is driven by a conformityseeking motive. Individuals have different thresholds that determine whether they will decide to adopt, based on the number and identity of those who have already adopted. The growth in the number of adopters motivates additional people, who are less susceptible to social influence, to join in and adopt the innovation. This creates a positive feedback process: The more people adopt the innovation, the greater the number of people whose threshold for joining has been satisfied (Schelling 1978, Rogers 2003, Lopez-Pintado and Watts 2008).

By contrast, economists have stressed the rationality of individual adoption decisions (Hall and Rosenberg 2010). Economic models assume that individuals adopt the new product or process if the expected benefit exceeds the expected cost. When individluals can assess the cost and benefit achieved by early adopters, this creates an opportunity for direct social learning. Even if this information is not perfect, for instance since unobserved case characteristics are likely to differ, it still is a valuable signal for the profitability of the innovation. Even the mere decision of others to adopt the product or process is informative. It signals that others deem the innovation profitable. Individuals can rely on these signals to update their own (prior) expectations through Bayesian learning (Chamley 2003). The signals can be more influential when previous adopters are better informed about the innovation's value. In a rational ex- 
pectations framework, the number of adoptions increases as relevant information accumulates (Bikhchandani, Hirshleifer et al. 1998). Individuals adopt at different times due to differences in their prior beliefs, the amount of information gathered and idiosyncratic resources and costs. If the innovation exhibits network externalities, the S-shaped adoption pattern is further caused by the fact that the benefit increases or the cost decreases as the innovation is more widely used. ${ }^{3}$

In this paper we examine how different types of information affects agents' decision to adopt an innovation. Each agent holds information regarding her own experience, and information concerning the number of previous adoptions that she observes and their outcomes. The three types of information can be distinguished, and their correlation with individual decisions to adopt an innovation can therefore be tested. In a private learning model, the agent's decision only depends on her own experiences. If social learning (Bayesian updating) or imitation matter, adoption decisions are (exclusively or additionally) explained by the fact that others are active in the market. The outcomes of past adoptions provide direct evidence about the utility of the product and can influence future adoptions only through social learning.

\section{b. Diffusion of Legal Innovations}

In comparison to the rich social science literature on the diffusion of innovative products, technologies and ideologies, the diffusion of legal innovation has attracted much less attention. Some papers have used the terminology of diffusion to address legal transplants from one legal system to another (Twining 2005, Twining 2006, Shur-Ofry, Fibich et al. 2016). Similarly, the diffusion paradigm has been used in explaining: patterns of adopting legal reforms among U.S. states (Walker 1969, Gray 1973) and cities (Lozner 2004); the migration of corporate law norms from one U.S. state to another (Romano 2006) and across different legal traditions (Spamann 2009); the diffusion of constitutional rights among countries (Goderis and Versteeg 2014); the diffusion of consumer protection legislation (Ford 1978) and the diffusion of doctrinal innovations in tort law or expert evidence among different state courts (Kritzer and Beckstrom 2007, Graham 2015). However, this research typically takes the legislating state or country as the primary decision-maker.

In a well-cited paper, Twining calls for expanding legal diffusion research on decisions made by individual addressees of the law: "In addition to macroscopic studies of large-scale receptions, there is a need for middle-order and microscopic analyses of particular examples of diffusion, involving detailed focus on interactions and perceptions of actors” (Twining 2005: 240). Yet, only few papers address the decisions made by non-governmental organizations to adopt legal innovations. Glick (2014) examines the decisions of colleges and universities to ing that motivations for adoption progressively shift as innovations diffuse. Whereas early adoptions are primarily explained by the search for economic benefits and initially foster diffusion based on rational assessment, late adoptions are triggered by mimicking and reflect increasing isomorphic pressures (Tolbert and Zucker 1983, Kennedy and Fiss 2009, Compagni, Mele et al. 2015). 
respond to legal changes, and the extent to which such decisions are made by mimicking the decisions of similar institutions. Rosen (2005), Barnes and Burke (2006) discuss responses of diverse organizations' to the accommodation provisions in the Americans with Disabilities Act and related state laws. Romano and Sanga (2017) study the adoption of exclusive forum clauses among public corporations and conclude that their diffusion is driven by the law firms representing those firms in the IPO. They describe the pattern of adoption as a light switch model, in which once a law firm includes a clause in an IPO, it does so for all subsequent IPOs. The pivotal role of law firms in the diffusion of legal remedies is further supported by our paper.

Rampa and Saraceno (2016) theoretically study the dynamics of setting precedents in courts, based on a micro-founded Bayesian model of the litigation decisions of individuals. Their model explores the dynamics involved when individuals observe past court decisions, update their beliefs concerning the merits of their cases, and consequently decide whether to file additional lawsuits on similar issues. These dynamics affect the development of precedents, as some litigation is encouraged by past decisions, whereas other litigation is discouraged.

In this paper, we expand the legal discourse on diffusion of innovations by focusing on legal professional's decision to utilize a new legal innovation already introduced into a legal system - the class action. We are interested not in the macro (state or organization) level, but in the micro level decision of individual lawyers and law firms to adopt a new legal remedy. Our approach differs from most previous research in three main respects:

The first respect is the unit of analysis: While legal studies have largely focused on the diffusion among large organizations, countries or legal systems, we study diffusion between individual adopters. Lawyers are vital agents in spreading any legal innovation: they are part of a relatively close network, with more social interactions and ties than the general public, thus stimulating a faster diffusion process. Furthermore, in comparison to the general public, lawyers are better informed about the outcomes and implications of legal reform, and they are better positioned to assess its risks, costs and benefits. Yet, in most cases of legal change the suitable unit of analysis would also include clients and judges, to changing degrees. Class actions are unique, in this respect, as they are almost exclusively initiated by attorneys, who search for available causes of action and then look for class members who may act as representatives (Fisch 1997, Hensler, Dombey-Moore et al. 2000: 72, Gilles and Friedman 2006).

The second point of departure refers to the nature of the adoption decision: Legal studies tend to focus on a binary one-time organizational decision to adopt a legal innovation. Once the legislator decides to adopt a new legal regime imported from another state, it is very difficult to turn back. This is similar to diffusion processes where one technology replaces another. By contrast, a lawyer's decision to utilize a new remedy like class action is much more similar to the diffusion of fashion trends. Her decision to file a class action does not have to be a onetime event; it can be part of a series of decisions. Given the right factual circumstances, at any point of time she can decide whether to file another class action. This has important implica- 
tions: first, there is no clear and external saturation point when all opportunities for filing a class action have been utilized. Second, when filing a class action for the second and third time, the decision is no longer influenced solely by others' decisions. The more class actions a lawyer files, the more she learns from her personal experience. As we will later discuss, the sequential nature of individual decisions to file permits a more fine-grained design for testing legal diffusion mechanisms.

Third, as economic diffusion models emphasize, previous adoption decisions can change the risks, costs and benefits of subsequent adoptions. While this is in some degree relevant to the study of legal transplants between legal systems (for example, through competition between states or countries, see Romano 2006, Goderis and Versteeg 2014), the dynamic effect intensifies when considering the dispersion of a legal innovation within a legal system. As Rampa and Saraceno (2016) have shown, each previous legal adoption has the power to change the legal surroundings and context - for example, by setting new precedents.

\section{Class Actions in Israel}

\section{a. Legal Background}

Class action is a unique procedure, incentivizing individual plaintiffs and attorneys to identify suitable causes of action, and to pursue them in court on behalf of an entire class of plaintiffs. During the past few decades, class action procedures have spread from the U.S. legal system to countries worldwide (Hensler 2016). However, the Israeli class action procedure is distinctive in its close resemblance to the American FRCP Rule 23, and sharing its fundamental characteristics (Klement and Klonoff 2018): First, in order to pursue a class action, a representative plaintiff must motion the court to certify it as such, and certification is conditioned upon various statutory requirements. Second, all plaintiffs who are members of the class defined in the certification decision are bound by its outcome, unless they actively opt out of the class action. Third, the possible remedies in a class action include monetary compensation, even if such compensation is not uniform among all class members. Fourth, the attorney's fee is awarded by the court, contingent upon winning the case or on settling it, and it depends, inter alia, on the value of the remedy awarded.

Hence, Israeli class actions present a pertinent case study for investigating the dynamics that underlie the spread of legal innovation. They are driven by lawyers, who initiate them, and make all litigation and settlement decisions. Moreover, class attorneys bear most of the costs and risk in class action litigation. They are awarded attorney fees by the court, which are usually set as a percentage of the common fund created in judgment or settlement. And they invest their time, whose reservation value is a cost they fully bear. We thus expect a lawyer's decision to file a class action to take into consideration the risks, costs and benefits from the suit. Furthermore, since class action certification requests and outcomes are required by law to be published in an online open register, we can assume that lawyers are well-informed about 
others' decisions to file class actions, as well as the outcomes in prior cases. The social networks and flow of information inducing diffusion of innovation is relatively active in class actions.

The Israeli parliament enacted the Class Action Law (CAL) in March 2006. The new law superseded all previous statutory arrangements, which had allowed class action procedures for a small number of specific causes of action in specified and well-defined sectors such as banking and insurance. ${ }^{4}$ Substantive and procedural requirements for submitting class actions set by these laws created significant barriers to class action certification, and thus yielded a very low number of class action filings - an average of fewer than 12 class actions per year. ${ }^{5}$ The new law maintained the substance-specific framework by designating the possible causes of action that may be brought as a class action. Nevertheless, those causes of action were prescribed in a much broader manner, rendering certification easier, especially in consumer protection (including banking and insurance), in labor and anti-discrimination cases, and in restitution lawsuits filed against unlawful payments collected by state and public authorities. The new legislation has also incorporated significant changes to the underlying procedural framework, mainly in prescribing elaborate arrangements for class settlement certification, in allowing the state specific protection when being sued, and in stipulating in great detail the considerations that courts should take into account when awarding class attorney and representative plaintiff remuneration.

Thus, the enactment of the CAL was meant to implement significant changes in the practice of class actions in Israel. As we demonstrate below, the CAL has indeed generated an increasing flow of class action filings, which culminated with an unprecedented annual filing rate of more than 1,200 lawsuits file in 2012, only six years after the enactment of the new law.

\section{b. Data and Variables}

We coded all motions to certify a class action ("cases," "suits" or "filings") submitted from December 2006, when the first suit was filed under the new law, through August 2012. The cases were drawn from computerized court records and were coded by law students who read all pertinent documents: pleadings, motions, hearing protocols, closing arguments and court decisions. A second tier of encoders randomly sampled approximately $10 \%$ of these cases for accuracy and internal reliability. Coding was found to be consistent in over $95 \%$ of the variables coded. For each case, we coded more than 200 variables, including information on the class representatives and their attorneys, the defendants and their attorneys, causes of action

4 For a description of these statutory class action procedures and a comparison with class action arrangements set in the CAL, see Klement and Weinshall-Margel (2016).

5 We searched the three main Israeli legal databases ("Nevo," "Takdin" and "Dinim") for all class actions submitted from the enactment of the first law allowing class actions in 1988 (the Securities Law of 1988) to 2006, and found only 215 cases, mostly submitted during the 1990s. The maximum number of cases per year was 19. The search included scanning the archives by search words for "class actions" (using a morphological search engine), as well as a direct search for claims according to the sections permitting class actions filings in the different laws. 
and other characteristics of the motion to certify a class action, and the remedies requested. For cases resolved by August 2013, which comprised 68\% of the suits, we also coded case outcomes.

During the six years we examined, 469 law firms filed a total of 2,057 class action suits. Most law firms operate as single lawyer offices, or are very small firms where all lawyers are signed as co-representing attorneys. ${ }^{6}$ As an indicator of the firm's visibility and prominence we used the well-known Israeli Dun's 100 directory, listing the most highly ranked Israeli Law Firms ${ }^{7}$. Only 9 plaintiff's law firms in our pool are listed in the directory. 279 law firms only filed a single case, 64 filed two cases, 30 filed three. On average they filed 4.28 cases. This high average chiefly results from a small number of law firms filing multiple class actions. The three most active law firms filed 258, 140 and 48 law suits, respectively. Some law firms filed multiple class actions on the same day.

From this raw data, we construct a panel data set. The panel runs from the day when the CAL entered into force until the last day at which we observe a new class action. This gives us a panel of length 2058 days. In our linear estimations, our dependent variables are two dummy variables. The dummy variable for market entry is 1 at the day when a law firm files its first class action; it is 0 otherwise. The dummy variable for market participation is 1 for any new class action filed by the law firm. ${ }^{8}$ For all days on which a firm has not filed a new class action, this dummy variable is 0 . We also report survival models. In these models the dependent variable is the (normalized) day when a law firm filed its first, or any, class action.

We explain market entry with indicators for social adoption and social outcomes, as defined in the theory section. Our indicator for social adoption is the total number of class actions that have been filed until a certain point in time. Indicators for social outcomes are calculated the following way: for each case that has been closed (by a court ruling, settlement, or withdrawal) we know if the attorney was awarded fees, and their amount. We also know if the representative plaintiff has borne a positive cost, and its amount. Until the last case has been filed, 837 cases close. On average, law firms earn a fee of 11,449 ILS per case. But only on $8.64 \%$ of these cases, the law firm was awarded a positive amount, with a maximum of 7,794,000 ILS. We define a successful outcome as a case in which a representing attorney received any amount of fee. For each point in time we calculate the success rate, by dividing the number of successful cases by the total number of cases that have been closed. An alternative indicator of success is the mean fee made on all cases that have been closed up till this point in time.

$657 \%$ of the suits were filed by a single lawyer office; $10.3 \%$ by a two-lawyers law-firm; and less than 7\% were submitted by a law-firm employing more than ten lawyers.

$7 \quad$ Rankings are undertaken in cooperation between economists of the Dun \& Bradstreet Israel Group and editorial staff of the Globes financial newspaper. For the criteria and method of ranking see http://duns100.globes.co.il/en/. Note that we only have rankings for 2014, i.e. for a moment in time when our time series had already started. We acknowledge the potential identification problem resulting from the possibility of reverse causality.

8 If the law firm files multiple class actions on the same day, for this day and law firm the data set has multiple entries. The same holds if more than one case filed by one and the same law firm closes on the same day. 
We explain participation with the same indicators for social adoption and outcomes, and additionally with the individual success rate. This is the number of cases that have been closed up till this point in time and on which this law firm has earned an attorney fee, divided by the number of all cases brought by this law firm that have been closed at this point in time.

\section{c. Hypotheses}

We test the following hypotheses:

\section{$\mathrm{H}_{1}$ Market Entry}

A law firm is more likely to file its first class action

a) the more class actions have been filed by other law firms

b) the more the class actions filed by other law firms have been successful

\section{$\mathbf{H}_{2}$ Market Participation}

A law firm is more likely to file a class action

a) the more class actions have been filed in the past

b) the more the class actions filed in the past have been successful

c) the more class actions filed by this law firm have been successful

\section{Results}

Figure 2 summarizes the data. ${ }^{9}$ During our period of observation, the cumulative distributions of new cases ("market participation”) and of first cases ("market entry”) grow continuously (right panel). While the cumulative distribution of market entry becomes approximately linear around day 1000, the cumulative distribution of market participation grows approximately exponentially over the entire period of observation. This suggests that the diffusion of the new legal remedy has not yet reached the characteristic point when growth slows down. This is reflected by the probability distribution (left panel). While the number of cases brought at each point in time grows rapidly, the number of first cases levels off in the second half of our period of observation. Note however that new firms continuously enter the market. It is only the rate of growth that becomes more or less constant. The left panel also shows that in the first half of our period of observation, only very few cases close (at day 1000 after the introduction of the remedy, 312 cases have been filed, but only 37 have been closed). Many more cases close afterwards. This means that, for the first 1000 days, there is not much direct evidence on the profitability of class action. The substantial period where there are very few outcomes but many case filings can help to isolate the effect of filing versus outcome measures.

9 In the graph, we bin the data by 50day windows. Fluctuations on individual days are so large that otherwise the graph would not be informative. All regressions work with individual observations. 


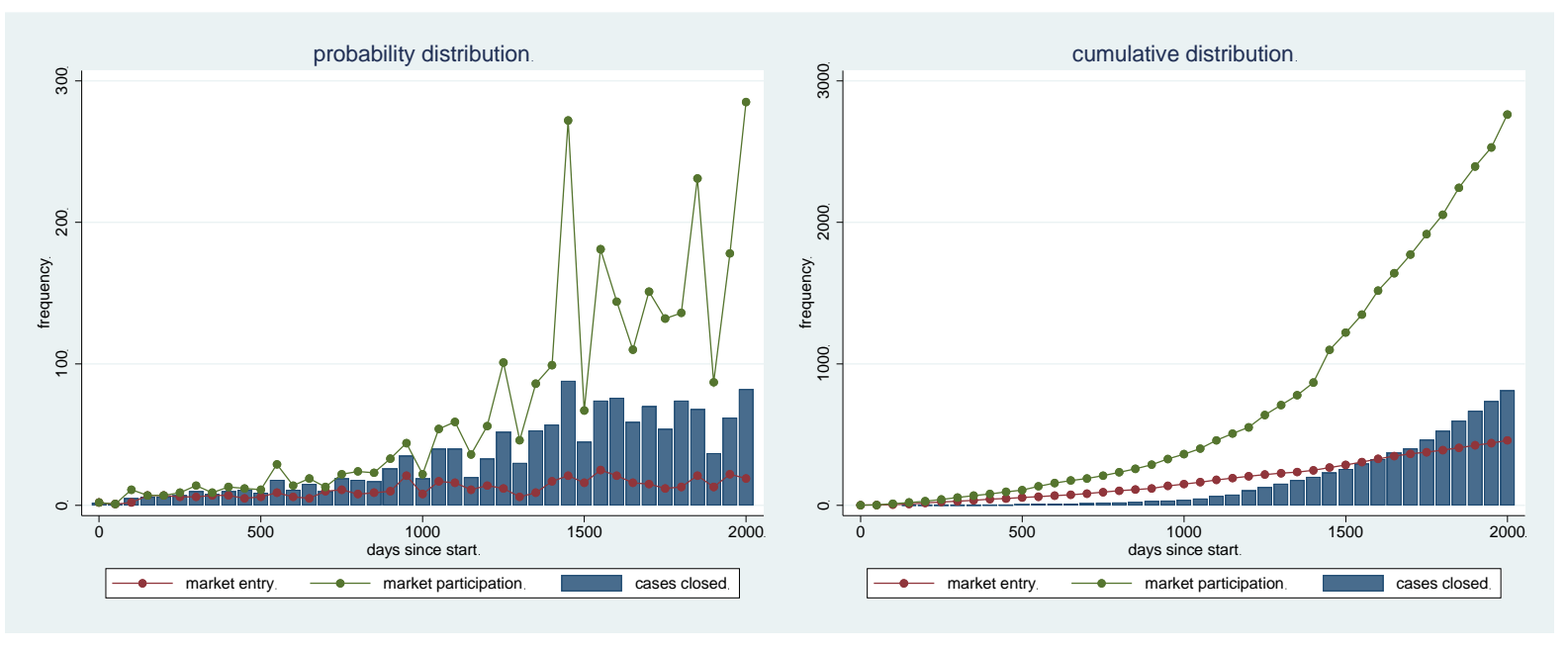

Figure 2

Market Entry and Market Participation Over Time

As Fehler! Verweisquelle konnte nicht gefunden werden. shows, highly visible law firms are critical for the diffusion of the new remedy: the cumulative probability that one of the 9 law firms in our pool that are listed in Dun's 100 directory files her first class action early on is much higher than for the remaining 460 law firms. The difference in the probability of early adoption is also highly significant. ${ }^{10}$ The listed, more prestigious firms are better suited to act as innovators and early adopters for several reasons. Their relatively high resources permit them to take more risks as they are capable of enduring losses; they employ high-skilled lawyers capable of litigating new types of cases; They are better placed to seek a position as "exemplary users” of the new innovation (Compagni, Mele et al. 2015). As they enjoy visibility and opinion leading status, their adoption of the new remedy might further induce others to adopt it, whether they merely wish to mimic prominent law firms or because adoption by these firms is a more informative signal for its potential profitability.

10 We regress the decision to bring a first class action on the number of days since the introduction of the remedy, interacted with a dummy that is 1 if the lawfirm is listed in the ranking. In keeping with the regressions presented in the next section, we add law firm fixed effects. This is why, through demeaning, the main effect of being ranked drops out. But the interaction effect is negative and significant at the $1 \%$ level. This additional regression is available from the authors upon request. 


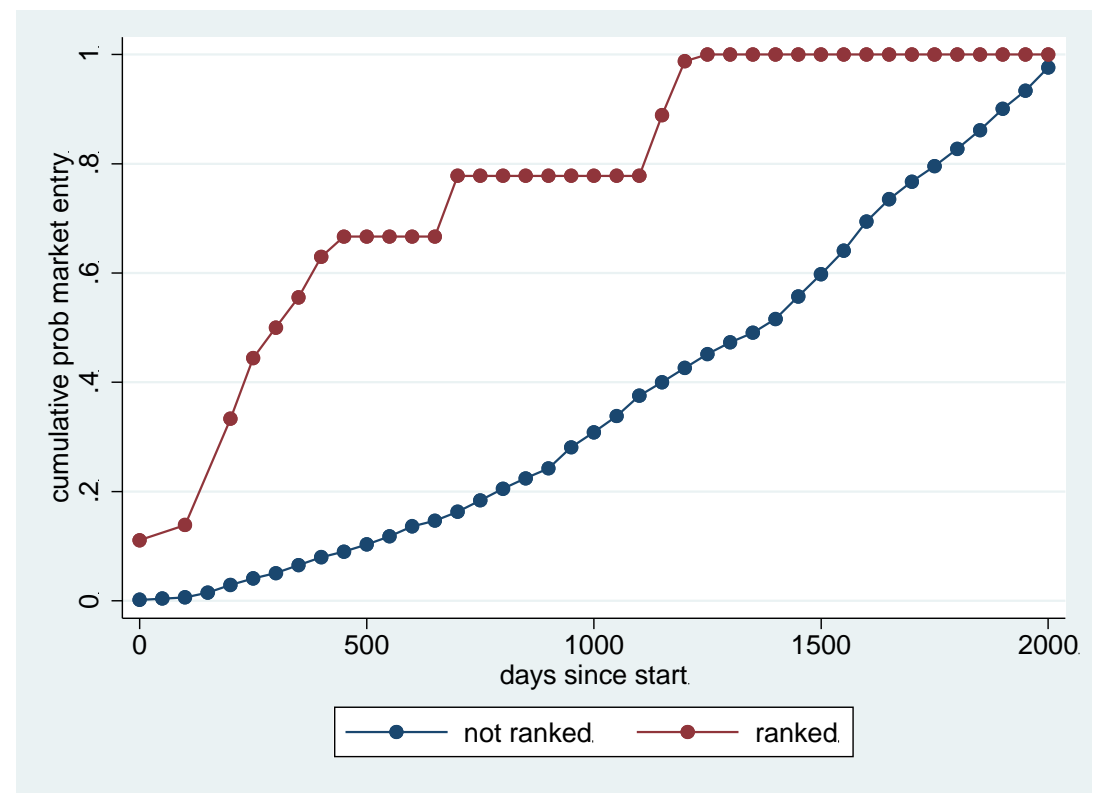

Figure 3

Market Entry by Rank of Law Firm

ranked: 9 law firms listed in Dun's top 100 Israeli law firms for 2014

Figure 4 collects market performance indicators from which a firm might be influenced. The left panel reports indicators that cover the complete past, from the first day when class action was legal up till the respective day. The number of all cases that have been brought grows exponentially during our entire period of observation. As more cases close around day 1000, the success rate grows, and hovers around 30\%: in about a third of all cases that close, the law firm earns a positive fee. As more cases close around day 1000, this ratio drops to approximately $10 \%$. The few cases that close around day 500 are very profitable. Law firms with a case closed between days 500 and 600 on average earn 46,128 ILS. Later profit drops, but rises again as more cases close after day 1000. A law firm then on average earns 35,379 ILS per case.

Alternatively, law firms might be influenced by experiences from the recent past. This information is available in the right panel. Obviously, recent experiences are more volatile. In some 50day periods, all closed cases have been successful. In some periods, law firms have earned large fees. 

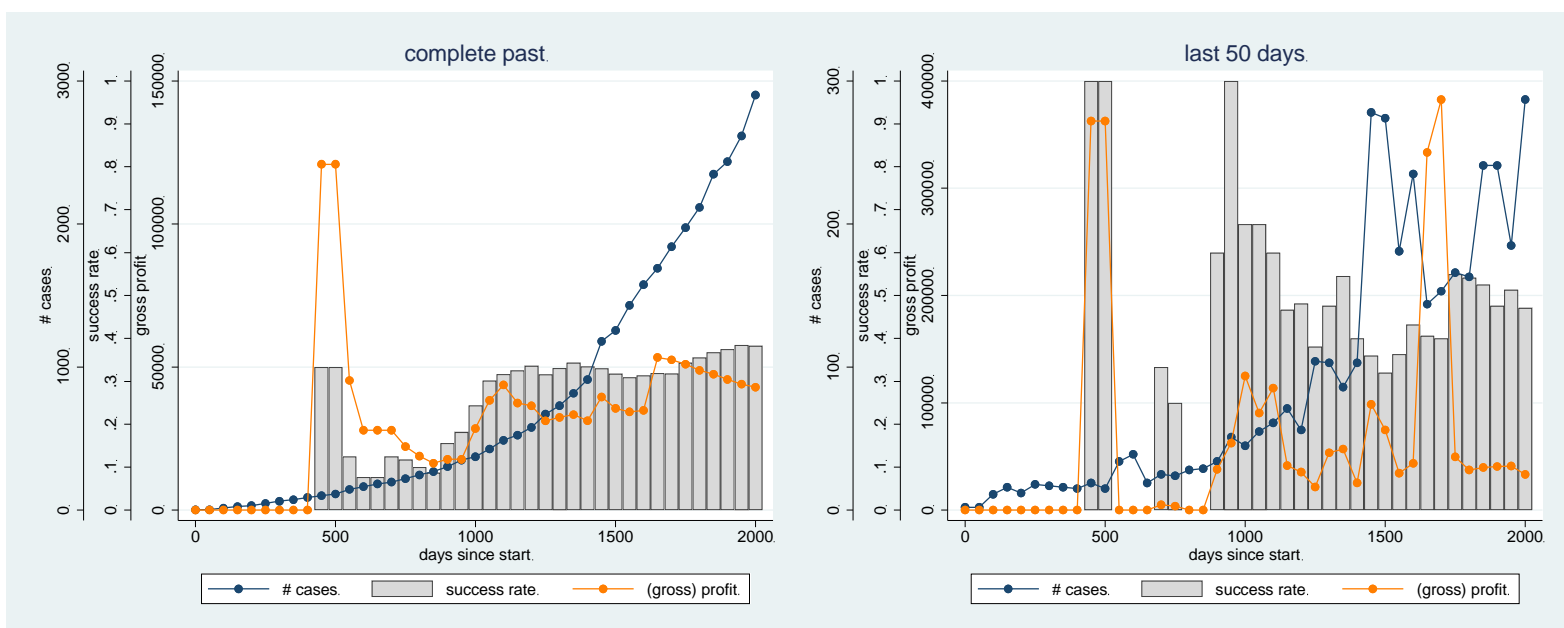

Figure 4

Development of Performance Indicators over Time

To test our hypotheses, we turn to regression analysis. We first focus on entry decisions. By definition, individual experience with the class action procedure cannot explain them. We use three alternative specifications. Table 1 and Table 2 report linear probability models. In these models, coefficients have a direct interpretation. They predict by how much the probability of a law firm filing its first class action changes if one of the experience indicators changes by one unit. ${ }^{11}$ A linear model assumes that the dependent variable could turn negative, which is impossible for probabilities. $^{12}$ To be on the safe side, in Table 3 we therefore also report Cox proportional hazard models that take this element of our data generating process into account. Note that Cox models predict "survival", which in our context means that a law firm does not yet enter the market. Consequently we expect all coefficients to have opposite sign. ${ }^{13}$

All regressions show that, if we do not control for performance indicators, the mere information that other law firms are entering the market induces further law firms to follow suit (models 2). The effect is already present in the period until day 1000, i.e. while there is very little information on profitability (models 1 ). ${ }^{14}$ But the effect becomes less pronounced if we

11 We estimate models with law firm fixed effects since for the models explaining market participation the Hausman test turns out significant. That way we use the same specification throughout. Standard errors take into account that choices per firm are not independent. We do not estimate a dynamic panel model since the number of observations per firm (2058) is very large, and more than 4 times as large as the number of law firms (469). Therefore the estimated coefficients are asymptotically consistent.

12 We do not have censored observations, i.e. law firms for which we do not observe whether they enter the market. This additional motive for specifying a survival model is therefore not present in our data.

13 Further note that we cannot replicate the regressions of Table 1 with a Cox model. A Cox model filters out the overall time trend, and explains how the independent variables shift this process, which is separately estimated. Now the frequency that other law firms have entered the market in the past is almost perfectly collinear with the overall time trend, which is why the models converge, but we do not get standard errors.

14 For two reasons, in all models coefficients are very small: by design, for each law firm, the dependent variable is 0 for all days but one. Consequently the probability to enter the market on one given day is very small in the first place, and the marginal effect of independent variables on this probability is small as well. Moreover the coefficient measures the effect of a one unit increase in the respective independent 
control for the market success rate (models 3), in particular when we explain market entry with experiences from the complete past (Table 1). As soon as it is available, meaningful social information becomes most important. The message is even clearer if we add both indicators to the specification (models 4): conditional on the probability of earning a fee, the amount of the expected fee even has a negative effect. This is intuitive: law firms are more likely to pick up that other law firms have had a success or a failure, rather than learning their exact fee. Since success rate and fee are positively correlated (Figure ), conditional on the more important performance indicator, the effect of the less important one turns negative. ${ }^{15}$

\begin{tabular}{|c|c|c|c|c|}
\hline & model 1 & model 2 & model 3 & model 4 \\
\hline $\begin{array}{l}\text { \# class } \\
\text { action } \\
\text { suits }\end{array}$ & $\begin{array}{l}.0000014^{\star \star *} \\
(.00000026)\end{array}$ & $\begin{array}{l}.00000021^{\star \star \star} \\
(.00000003)\end{array}$ & $\begin{array}{l}.00000008^{+} \\
(.00000004)\end{array}$ & $\begin{array}{c}.00000005 \\
(.00000005)\end{array}$ \\
\hline $\begin{array}{c}\text { market } \\
\text { success } \\
\text { rate }\end{array}$ & & & $\begin{array}{l}.00097^{\star \star \star} \\
(.00026)\end{array}$ & $\begin{array}{l}.0016^{\star \star \star} \\
(.00035)\end{array}$ \\
\hline $\begin{array}{c}\text { market } \\
\text { mean fee }\end{array}$ & & & & $\begin{array}{l}-.00000000042^{\star} \\
(.00000000017)\end{array}$ \\
\hline cons & $\begin{array}{l}.00014^{\star \star \star} \\
(.000041)\end{array}$ & $\begin{array}{l}.00033^{\star \star \star} \\
(.00003)\end{array}$ & $\begin{array}{l}.00024^{\star \star \star} \\
(.000039)\end{array}$ & $\begin{array}{l}.00026^{\star \star \star} \\
(.00004)\end{array}$ \\
\hline N obs & 469,000 & 965,202 & 965,202 & 965,202 \\
\hline $\begin{array}{l}\text { N law- } \\
\text { firms }\end{array}$ & 469 & 469 & 469 & 469 \\
\hline
\end{tabular}

Table 1

Explaining Decision to Enter the Market with Experiences from Complete Past

\author{
linear probability models with law firm fixed effects \\ $\mathrm{dv}$ : a dummy that is one on the day that a law firm files its first class action suit \\ days 0 - 2058 (last day when a new class action has been filed) \\ \# class action suits: total number of class actions suits that have been filed until the previous day \\ success rate: number of all class action cases closed until the previous day and yielding a positive profit / \\ number of all class action cases closed until the previous day \\ standard errors (for choices in law firms) in parenthesis \\ all effects also go through if we drop the top 2 or top 5 law firms from the sample \\ if we only consider single lawyer lawfirms, on model 4 we do not find a significant effect of market mean fee \\ ${ }^{\star * *} p<.001,{ }^{\star *} p<.01,{ }^{*} p<.05,+p<.1$
}

variable, and the independent variables of interest are themselves large. Attention should therefore be on significance, more than on the size of the coefficients.

15 If we interact the success rate with the mean fee, the mean fee turns out insignificant. If we use all experiences, there is a weakly significant $(p=.058)$ negative interaction effect. If we use experiences from the last 50 days, the negative interaction is significant at conventional levels. This suggests that law firms discount spectacular success of their peers, and are more interested in the ordinary outcomes of cases. These additional regressions are available from the authors upon request. Note that we cannot replicate this test with the Cox models as they are non-linear, so that interaction effects are not properly defined. 


\begin{tabular}{|c|c|c|c|c|}
\hline & model 1 & model 2 & model 3 & model 4 \\
\hline $\begin{array}{l}\text { \# class } \\
\text { action } \\
\text { suits }\end{array}$ & $\begin{array}{l}.000017^{\star \star \star} \\
(.0000025)\end{array}$ & $\begin{array}{l}.0000028^{* * *} \\
(.00000032)\end{array}$ & $\begin{array}{l}.0000022^{\star * *} \\
(.00000036)\end{array}$ & $\begin{array}{l}.0000021^{\star \star *} \\
(.00000036)\end{array}$ \\
\hline $\begin{array}{l}\text { market } \\
\text { success } \\
\text { rate }\end{array}$ & & & $\begin{array}{l}.00041^{\star \star \star} \\
(.00011)\end{array}$ & $\begin{array}{l}.00053^{\star \star \star} \\
(.00013)\end{array}$ \\
\hline $\begin{array}{c}\text { market } \\
\text { mean fee }\end{array}$ & & & & $\begin{array}{l}-.000000000079^{+} \\
(.000000000043)\end{array}$ \\
\hline cons & $\begin{array}{c}.000033 \\
(.000048) \\
\end{array}$ & $\begin{array}{l}.0003^{\star \star \star} \\
(.000031)\end{array}$ & $\begin{array}{l}.00024^{\star \star \star} \\
(.000035)\end{array}$ & $\begin{array}{l}.00024^{\star \star \star} \\
(.000035)\end{array}$ \\
\hline $\mathrm{N}$ obs & 469,000 & 965,202 & 965,202 & 965,202 \\
\hline $\begin{array}{l}\text { N law- } \\
\text { firms }\end{array}$ & 469 & 469 & 469 & 469 \\
\hline
\end{tabular}

Table 2

Explaining Decision to Enter the Market with Experiences from Last 50 Days

linear probability models with law firm fixed effects

dv: a dummy that is one on the day that a law firm files its first class action suit days 0 - 2058 (last day when a new class action has been filed)

\# class action suits: total number of class actions suits that have been filed until the previous day during the last 50 days success rate: number of all class action cases closed until the previous day and yielding a positive profit / number of all class action cases closed until the previous day, during the last 50 days standard errors (for choices in law firms) in parenthesis

all effects also go through if we drop the top 2 or top 5 law firms from the sample, or if we only consider single lawyer lawfirms

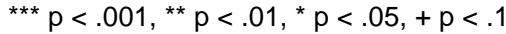

\begin{tabular}{|c|c|c|c|c|}
\hline & model 1 & model 2 & model 3 & model 4 \\
\hline $\begin{array}{l}\text { \# class } \\
\text { action } \\
\text { suits }\end{array}$ & $\begin{array}{c}-.230 * \star \star \\
(.021)\end{array}$ & $\begin{array}{l}-.027 * \star \star \\
(.001)\end{array}$ & $\begin{array}{c}-.024^{\star \star \star} \\
(.001)\end{array}$ & $\begin{array}{c}-.024^{\star \star \star} \\
(.001)\end{array}$ \\
\hline $\begin{array}{c}\text { market } \\
\text { success } \\
\text { rate }\end{array}$ & & & $\begin{array}{c}-3.963^{\star \star \star} \\
(.434)\end{array}$ & $\begin{array}{c}-3.978 * \star \star \\
(.438)\end{array}$ \\
\hline $\begin{array}{c}\text { market } \\
\text { mean fee }\end{array}$ & & & & $\begin{array}{c}.00000019 \\
(.00000081)\end{array}$ \\
\hline N obs & 144 & 468 & 468 & 468 \\
\hline
\end{tabular}

Table 3

Explaining Decision to Enter the Market with Experiences from Last 50 Days

Cox proportional hazard models

dv: day when a law firm files its first class action suit one observation lost as (by design) failure is on first day of observation

days 0 - 2058 (last day when a new class action has been filed)

\# class action suits: total number of class actions suits that have been filed until the previous day during the last 50 days success rate: number of all class action cases closed until the previous day and yielding a positive profit / number of all class action cases closed until the previous day, during the last 50 days standard errors (for choices in law firms) in parenthesis

all effects also go through if we drop the top 2 or top 5 law firms from the sample, or if we only consider single lawyer lawfirms

$$
{ }^{\star \star *} p<.001,{ }^{* *} p<.01,{ }^{*} p<.05,+p<.1
$$

We conclude:

Result 1: The decision to file a class action is explained by class action filings of other law firms and their success rate. 
The picture becomes even clearer if we consider not only the decision by a law firm to file its first class action, but any decision to bring a class action, i.e. if we shift attention from market entry to market participation. We again report three specifications: a linear model that explains the decision to file a class action with experiences from the complete past (Table 4) or from the last 50 days (Table 5), and the Cox proportional hazard model that corresponds to the latter model (Table 6). ${ }^{16}$ We find that, independent of specification, the number of cases that have been brought, their rate of success and the success rate of cases brought by this one law firm independently and conditional on each other explain choices. ${ }^{17}$ If we consider all experiences, the mean fee of all cases by all law firms that have been closed in the past again has a significant negative effect: law firms focus on success or failure, not on the amount to be gained. ${ }^{18}$

\begin{tabular}{|c|c|c|c|c|}
\hline & model 1 & model 2 & model 3 & model 4 \\
\hline \# class action suits & $.0000015^{\star \star \star}$ & $.0000011^{\star \star \star}$ & $.0000010^{\star \star \star}$ & $.00000080^{\star \star \star}$ \\
& $(.00000005)$ & $(.00000008)$ & $(.00000008)$ & $(.000000085)$ \\
\hline market success rate & & $.0032^{\star \star \star}$ & $.0050^{\star \star \star}$ & $.0049^{\star \star \star}$ \\
& & $(.00048)$ & $(.00065)$ & $(.00065)$ \\
\hline market mean fee & & & $-.000000013^{\star \star \star}$ & $-.000000012^{\star \star \star}$ \\
& & & $(.0000000032)$ & $(.0000000032)$ \\
\hline individual success rate & & & & $.0077^{\star \star \star}$ \\
& & & & $(.00041)$ \\
\hline Cons & $.00054^{\star \star \star}$ & $.00024^{\star \star \star}$ & $.00029^{\star \star \star}$ & $.00031^{\star \star \star}$ \\
& $(.000056)$ & $(.000072)$ & $(.000073)$ & $(.000073)$ \\
\hline N obs & 965,202 & 965,202 & 965,202 & 965,202 \\
\hline N lawfirms & 469 & 469 & 469 & 469 \\
\hline
\end{tabular}

Table 4

\title{
Explaining Decision to Participate in the Market with Experiences from Complete Past
}

\author{
linear probability models with law firm fixed effects \\ $\mathrm{dv}$ : a dummy that is one for any new class action suit filed by a law firm \\ all models cover days 0 - 2058 (last day when a new class action has been filed) \\ \# class action suits: total number of class actions suits that have been filed up till a given day \\ market success rate: number of all class action \\ $\mathrm{n}$ cases closed until a given day and yielding a positive profit / \\ number of all class action cases closed until a given day \\ individual success rate: number of all class action cases filed by this law firm and closed until a given day and yielding a positive \\ profit / number of all class action cases filed by this law firm and closed until a given day \\ standard errors (for choices in law firms) in parenthesis \\ all effects also go through if we drop the top 2 or top 5 law firms from the sample, or if we only consider single lawyer lawfirms \\ $\star \star \star ~ p<.001,{ }^{\star *} p<.01,{ }^{\star} p<.05$
}

16 We again do not have a Cox model explaining „survival“ with all experiences as the number of cases brought in the past would be almost perfectly collinear with the time trend.

17 Conditional on the individual success rate past individual profit does not significantly explain the choice to again participate in the market. Without this control variable, past profit is positive and significant. These additional regressions are available from the authors upon request.

18 Again results look similar if we replace experiences from the entire past with experiences from the last 50 days. Results look also similar, and all effects go through, if we drop the two law firms with more than 100 cases, or the five law firms with more than 40 cases, from the estimation. Hence in terms of their market participation choices, these law firms are not outliers. These additional regressions are available from the authors upon request. 


\begin{tabular}{|c|c|c|c|c|}
\hline & model 1 & model 2 & model 3 & model 4 \\
\hline \# class action suits & $.000018^{\star \star \star}$ & $.000015^{\star \star \star}$ & $.000015^{\star \star \star}$ & $.000013^{\star \star \star}$ \\
& $(.00000059)$ & $(.0000006)$ & $(.00000066)$ & $(.00000066)$ \\
\hline market success rate & & $.0016^{\star \star \star}$ & $.0017^{\star \star \star}$ & $.0014^{\star \star \star}$ \\
& & $(.0002)$ & $(.00024)$ & $(.00024)$ \\
\hline market mean fee & & & -.00000000052 & .000000000062 \\
& & & $(.0000000008)$ & $(.0000000008)$ \\
\hline individual success rate & & & & $.039^{\star \star \star}$ \\
& & & & $(.00064)$ \\
\hline cons & $.0005^{\star \star \star}$ & $.00028^{\star \star \star}$ & $.00028^{\star \star \star}$ & $.00031^{\star \star \star}$ \\
& $(.000058)$ & $(.00006)$ & $(.00006)$ & $(.000064)$ \\
\hline N obs & 965,202 & 965,202 & 965,202 & 965,202 \\
\hline N lawfirms & 469 & 469 & 469 & 469 \\
\hline
\end{tabular}

Table 5

Explaining Decision to Participate in the Market with Experiences from Last 50 Days linear probability models with law firm fixed effects

$d v$ : a dummy that is one on the day that a law firm files its first class action suit days 0 - 2058 (last day when a new class action has been filed)

\# class action suits: total number of class actions suits that have been filed until the previous day during the last 50 days success rate: number of all class action cases closed until the previous day and yielding a positive profit / number of all class action cases closed until the previous day, during the last 50 days standard errors (for choices in law firms) in parenthesis

all effects also go through if we drop the top 2 or top 5 law firms from the sample if we only consider single lawyer lawfirms, the effect of the market mean fee turns negative and significant $\star \star \star ~ p<.001, * \star p<.01,{ }^{*} p<.05,+p<.1$

\begin{tabular}{|c|c|c|c|c|}
\hline & model 1 & model 2 & model 3 & model 4 \\
\hline \# class action suits & $\begin{array}{c}-.022^{\star \star \star} \\
(.001)\end{array}$ & $\begin{array}{c}-.021^{\star \star \star} \\
(.001)\end{array}$ & $\begin{array}{c}-.021^{\star \star \star} \\
(.001)\end{array}$ & $\begin{array}{c}-.021^{\star \star \star} \\
(.001)\end{array}$ \\
\hline market success rate & & $\begin{array}{c}-5.155^{\star \star \star} \\
(.327)\end{array}$ & $\begin{array}{c}-5.161^{\star \star \star} \\
(.325)\end{array}$ & $\begin{array}{c}-5.096^{\star \star \star} \\
(.328)\end{array}$ \\
\hline market mean fee & & & $\begin{array}{c}.000 \\
(.000)\end{array}$ & $\begin{array}{c}.000 \\
(.000)\end{array}$ \\
\hline individual success rate & & & & $\begin{array}{c}-.321^{\star \star} \\
(.114)\end{array}$ \\
\hline N obs & 1630 & 1630 & 1630 & 1630 \\
\hline N lawfirms & 468 & 468 & 468 & 468 \\
\hline
\end{tabular}

Table 6

Explaining Decision to Participate in the Market with Experiences from Last 50 Days

Cox proportional hazard model

dv: day when a law firm files a class action suit one observation lost as (by design) failure is on first day of observation

days 0 - 2058 (last day when a new class action has been filed)

\# class action suits: total number of class actions suits that have been filed until the previous day during the last 50 days success rate: number of all class action cases closed until the previous day and yielding a positive profit / number of all class action cases closed until the previous day, during the last 50 days standard errors (clustered for law firms) in parenthesis

all effects also go through if we drop the top 2 or top 5 law firms from the sample if we only consider single lawyer lawfirms, the effect of the market mean fee turns positive and significant

$$
{ }^{\star * *} p<.001,{ }^{* *} p<.01,{ }^{*} p<.05,^{+} p<.1
$$


We conclude:

Result 2: The decision to file a class action is explained by

a) other law firms' filings

b) other law firms' success

c) the success of the law firm in question

\section{Discussion}

One might have thought that law firms who venture their own money behave in ways that are not too different from the agents of economic textbooks. This is not, however, how Israeli law firms have reacted to the introduction of the class action procedure.

Since class action lawyers act on a contingent fee basis, risks and opportunities are chiefly their own. Profit maximizing lawyers would have independently assessed the profitability of this newly opened line of business, and would have brought cases if expected benefits outweighed expected costs. Yet for more than two years, the new remedy was rarely used. Only 1000 days after its introduction has its use become more frequent, culminating in an approximately exponential pattern of adoption.

Our findings suggest that legal innovations can diffuse in a manner similar to the way novel products diffuse after they are first introduced into the market. First movers, innovators and early adopters that file class actions, tend to be the more prestigious firms, who are better able to endure uncertainty and risk, employ high-skilled lawyers and enjoy opinion leadership status. Social information then plays a significant and independent role in the decisions to use the legal innovation, and its significance increase with the number of adoptions.

In principle, this pattern could be explained both on sociological and on economic grounds. The mechanism behind the observed diffusion patterns can be one of social herding, which is motivated by lawyers' tendency to imitate and conform with others. Alternatively, lawyers can interpret other lawyers' filings as an informative signal about the profitability of class actions. We do find, however, that the decision to enter this market, and to be active in it, are not only explained by the number of class actions filed by other law firms. Conditional on this effect, market participation is also explained by the observable profitability of class actions, and by the respective law firm's own success rate in this line of business. The latter effects transcend imitation and support rational profit maximization.

We have focused on class actions since this is an area of law where lawyers initiate litigation, and if they deem a case promising, search for a plaintiff to represent. Other types of legal innovations often involve decisions made by the general public and not by legal professionals; they mostly concern substantive as opposed to procedural law; and their utilization, or in the parlance of the innovation diffusion literature, their 'adoption', as well as their outcomes, are 
not necessarily observed by the general public. For all of these reasons, future research is needed to test if our findings can be generalized to the adoption of other legal innovations.

Why and how does the use of legal reform spread? This research suggests that the answer can be found in the diffusion patterns that have been observed in the innovation literature. When considering legal reform, legislators should take individual and social motivations into account. Information about the adoption of such reform, as well as its outcomes, will likely impact the speed with which it will be transformed from law on the books to law in practice. 


\section{Bibliography}

BAPtista, Rui (1999). "The Diffusion of Process Innovations. A Selective Review." International Journal of the Economics of Business 6(1): 107-129.

Barnes, Jeb And Thomas F Burke (2006). "The Diffusion of Rights. From Law on the Books to Organizational Rights Practices." Law \& Society Review 40(3): 493-524.

BAss, Frank M (1969). "A New Product Growth Model for Consumer Durables." Management Science 15(5): 215-227.

Bikhchandani, Sushil, David Hirshleifer and IVo Welch (1998). "Learning from the Behavior of Others. Conformity, Fads, and Informational Cascades." Journal of Economic Perspectives 12(3): 151-170.

CHAMLey, Christopher (2003). Rational Herds. Cambridge, Cambridge University Press

Compagni, Amelia, Valentina Mele and Davide Ravasi (2015). "How Early Implementations Influence Later Adoptions of Innovation. Social Positioning and Skill Reproduction in the Diffusion of Robotic Surgery." Academy of Management Journal 58(1): 242278.

Diebolt, Claude, Tapas Mishra And Mamata Parhi (2016). Dynamics of Distribution and Diffusion of New Technology. A Contribution to the Historical, Economic and Social Route of a Developing Economy. New York, Springer.

Engel, Christoph (2008). "Learning the Law." Journal of Institutional Economics 4: 275297.

FisCH, JiLl E (1997). "Class Action Reform," Qui Tam", and the Role of the Plaintiff." Law and Contemporary Problems 60(4): 167-202.

Ford, GARY T (1978). "Adoption of Consumer Policies by States. Some Empirical Perspectives." Journal of Marketing Research 15: 49-57.

Gilles, Myriam And Gary B Friedman (2006). "Exploding the Class Action Agency Costs Myth. The Social Utility of Entrepreneurial Lawyers." University of Pennsylvania Law Review 155(1): 103-164.

GlicK, DAVID M (2014). "Learning by Mimicking and Modifying. A Model of Policy Knowledge Diffusion with Evidence from Legal Implementation." Journal of Law, Economics, and Organization 30(2): 339-370.

Goderis, Benedikt And Mila Versteeg (2014). "The Diffusion of Constitutional Rights." International Review of Law and Economics 39: 1-19.

Graham, Kyle (2015). "The Diffusion of Doctrinal Innovations in Tort Law." Marquette Law Review 99: 75-178.

Gray, Virginia (1973). "Innovation in the States. A Diffusion Study." American Political Science Review 67(04): 1174-1185. 
Greenhalgh, Trisha, Glenn Robert, Fraser Macfarlane, Paul Bate and Olivia KyrIAKIDOU (2004). "Diffusion of Innovations in Service Organizations. Systematic Review and Recommendations." Milbank Quarterly 82(4): 581-629.

Hall, Bronwyn H and Nathan Rosenberg (2010). Handbook of the Economics of Innovation. Dordrecht, Elsevier.

Hensler, Deborah R (2016). The Global Landscape of Collective Litigation. Class Actions in Context. How Culture, Economics and Politics Shape Collective Litigation. D. R. Hensler, C. Hodges and I. Tzankova. Cheltenham, Elgar: 3-22.

Hensler, Deborah R, Bonnie Dombey-Moore, Elizabeth Giddens, Jennifer Gross and ErIK Moller (2000). Class Action Dilemmas. Pursuing Public Goals for Private Gain. Santa Monica, Rand Corporation.

Kennedy, Mark Thomas and Peer Christian Fiss (2009). "Institutionalization, Framing, and Diffusion. The Logic of TQM Adoption and Implementation Cecisions among US Hospitals." Academy of Management Journal 52(5): 897-918.

Klement, Alon and Robert H Klonoff (2018). "Class Actions in the US and Israel. A Comparative Approach." Theoretical Inquiries in Law ***: ***.

Klement, Alon and Keren Weinshall-Margel (2016). "Cost-Benefit Analysis of Class Actions - An Israeli Perspective." Journal of Institutional and Theoretical Economics 172: $75-103$.

Kritzer, Herbert M And Darryn C Beckstrom (2007). "Daubert in the States: Diffusion of a New Approach to Expert Evidence in the Courts." Journal of Empirical Legal Studies 4(4): 983-1006.

Lopez-Pintado, Dunia And Duncan J WATts (2008). "Social Influence, Binary Decisions and Collective Dynamics." Rationality and Society 20(4): 399-443.

LOZNER, STACY LAIRA (2004). "Diffusion of Local Regulatory Innovations. The San Francisco CEDAW Ordinance and the New York City Human Rights Initiative." Columbia Law Review 104: 768-800.

Rampa, Giorgio and Margherita Saraceno (2016). "Beliefs, Precedent, and the Dynamics of Access to Justice. A Bayesian Microfounded Model." American Law and Economics Review 18(2): 272-301.

Rogers, EveretT M (2003). Diffusion of Innovations. New York, Free Press.

Romano, RoBerta (2006). "The States as a Laboratory. Legal Innovation and State Competition for Corporate Charters." Yale Journal on Regulation 23: 209-248.

Romano, Roberta And Sarath Sanga (2017). "The Private Ordering Solution to Multiforum Shareholder Litigation." Journal of Empirical Legal Studies 14(1): 31-78.

Rosen, Robert (2005). "Resistances to Reforming Corporate Governance. The Diffusion of QLCC's." Fordham Law Review 74: 1251-1317. 
SCHELLING, ThOMAs C. (1978). Micromotives and Macrobehavior. New York, Norton

SHuR-Ofry, Michal (2009). "Popularity as a Factor in Copyright Law." University of Toronto Law Journal 59(4): 525-578.

Shur-Ofry, Michal, Gadi Fibich AND Shira Wultz-Green (2016). The Diffusion of Legal Innovation. A Mathematical Modeling Approach.

https://papers.ssrn.com/sol3/papers.cfm?abstract_id=2730461.

Spamann, Holger (2009). "Contemporary Legal Transplants. Legal Families and the Diffusion of (Corporate) Law." Brigham Young University Law Review: 1813-1878.

Strang, David (1991). "Adding Social Structure to Diffusion Models. An Event History Framework." Sociological Methods \& Research 19(3): 324-353.

Tolbert, Pamela S And Lynne G Zucker (1983). "Institutional Sources of Change in the Formal Structure of Organizations. The Diffusion of Civil Service Reform, 1880-1935." Administrative Science Quarterly 28: 22-39.

Twining, WiLliam (2004). "Diffusion of Law. A Global Perspective." Journal of Legal Pluralism and Unofficial Law 36(49): 1-45.

TwiniNG, WiLLIAM (2005). "Social Science and Diffusion of Law." Journal of Law and Society 32(2): 203-240.

Twining, William (2006). "Diffusion and Globalization Discourse." Harvard International Law Journal 47: 507-516.

WALKER, JACK L (1969). "The Diffusion of Innovations Among the American States." American Political Science Review 63(03): 880-899.

WestBrook, David A (2006). "Keynote Address Theorizing the Diffusion of Law. Conceptual Difficulties, Unstable Imaginations, and the Effort To Think Gracefully Nonetheless." Harvard International Law Journal 47: 489-506.

Young, H Peyton (2009). "Innovation Diffusion in Heterogeneous Populations. Contagion, Social Influence, and Social Learning." American Economic Review 99(5): 1899-1924. 